\title{
HUBUNGAN ANTARA KECERDASAN SPIRITUAL DENGAN STRES KERJA PADA PERAWAT RS DI KLATEN
}

\author{
Ridwan Umamit \\ Siti Mulyani \\ Fakultas Psikologi Universitas Ahmad Dahlan \\ Email: ajivita@yahoo.com
}

\begin{abstract}
This study was aimed to examine the correlation of spritual intteligence and job stress in nurse. This hypothesis posed in this study were there is a negative correlation between spiritual intelligence and job stress. The subject of this study were nurse of emergency and inpatient unit at the hospital in Klaten, totaling 101 people. Data were collected by using spiritual intelligence and job stress scale. The data is was then statistically analyzed using Pearson product moment analysis with SPSS SPSS version 15.0 for windows. The analysis found correlation coefficient of $(r \neg x y)=-0.315, p=0.001(p<0.01)$, the determinant coefficient $r 2=0.099$, indicates that the effective contribution of spiritual intelligence to job stress by $9.9 \%$. Base on the analyse can be concluded that there was a significant negative correlation between spiritual intelligence with work stress on nurses. These results illustrate that the higher spiritual intelligence, the lower the stress of work. Conversely the lower the higher spiritual intelligence stress of work or hypothesis is accepted
\end{abstract}

Keywords: Spritual Intteligence, Job stress, Nurse

\section{INTISARI}

Penelitian ini bertujuan untuk melihat hubungan antara kecerdasan spiritual dengan stres kerja pada perawat. Hipotesis yang diajukan pada penelitian ini adalah ada hubungan negatif antara kecerdasan spiritual dan stress kerja. Subjek yang digunakan dalam penelitian ini adalah perawat bagian UGD dan Rawat Inap di Rumah Sakit Klaten yang berjumlah 101 orang. Alat ukur yang digunakan adalah skala kecerdasan spiritual dan skala stres kerja. Analisis data yang digunakabn dalam penelitian ini adalah teknik korelasi product moment dari Pearson dengan bantuan SPSS versi 15.0 for windows. Hasil analisis data menunjukkan koefisien korelasi sebesar $\left(r_{\mathrm{xy}}\right)=-0,315$ dengan $\mathrm{p}=0,001(\mathrm{p}<0,01)$, koefisien determinan $r^{2}=0,099$ menunjukkan bahwa sumbangan efektif kecerdasan spiritual terhadap stres kerja sebesar 9,9\%. Berdasarkan hasil penelitian yang telah dilakukan dapat ditarik kesimpulan bahwa ada hubungan negatif yang sangat signifikan antara kecerdasan spiritual dengan stres kerja pada perawat. Hasil ini menggambarkan bahwa semakin tinggi kecerdasan spiritual maka semakin rendah stres kerja. Sebaliknya semakin rendah kecerdasan spiritual maka semakin tinggi stres kerja atau hipotesis diterima.

Kata Kunci: Kecerdasan Spiritual, Stres Kerja, Perawat

P)

ada era globalisasi saat ini, persaingan antar perusahaan semakin ketat, karena investor asing mulai menembus pasar Indonesia sehingga persaingan terjadi bukan hanya antar perusahaan di Indonesia tetapi juga dengan perusahaan asing. Kondisi tersebut juga terjadi pada bisnis rumah sakit, hal tersebut terlihat pada rumah sakit berstandar international mulai bermunculan di kota-kota besar. Situasi tersebut menyebabkan setiap rumah sakit berusaha mencip takan keunggulan kompetitif agar mampu memenangkan persaingan. 
Perawat dan dokter merupakan ujung tombak dari rumah sakit karena berhubungan langsung dengan pasien. Kondisi tersebut juga menyebabkan perawat juga menjadi salah satu target dari rumah sakit yang ingin ditingkatkan kompetensinya karena kualitas kerja perawat mempengaruhi tingkat kepercayaan pasien pada suatu rumah sakit. Seorang perawat bersama dokter juga mempunyai tugas dan tanggung jawab memperjuangkan keselamatan jiwa pasien, sehingga perawat dituntut selalu sigap dan tanggap untuk membantu pasien yang membutuhkan pertolongan dan penanganan medis, karena itu pekerjaannya menuntut ketahanan kerja yang tinggi. Perawat yang ditempatkan di UGD (Unit Gawat Darurat) tuntutan kerjanya lebih tinggi jika dibandingkan dengan unit lain karena dituntut untuk selalu siap siaga dalam penanganan pasien terutama pada saat ada pasien yang datang karena mengalami kecelakaan dan kondisi kritis. Perawat yang bertugas di unit UGD tetap dituntut sikap yang tenang meski sedang menghadapi pasien yang kritis, serta harus mampu menenangkan keluarga pasien yang sedang dalam kondisi panik. Situasi tersebut dapat mempengaruhi kondisi psikologis perawat sehingga terkadang tampak beberapa gejala stres seperti yang dikemukakan oleh Beehr dan Newman (Rice, 1999) diantaranya cemas, gugup, konsentrasi terganggu, mudah marah dan bahkan nafsu makan berkurang.

Stres kerja menurut Anoraga (2001) merupakan kondisi yang muncul akibat reaksi seseorang dengan pekerjaan dan lingkungan kerjanya. Sedangkan Greenberg \& Baron (Yeh, H.R., Chi, \& Chiou, 2008) mendefinisikan stres kerja sebagai respon emosional, kognitif, dan fisiologis pada individu ketika berinteraksi dengan sumbersumber tekanan eksternal. Segala macam bentuk stres pada dasarnya disebabkan oleh kurang mengertinya individu terhadap keterbatasan-keterbatasannya sendiri, ketidakmampuan untuk melawan keterbatasan inilah yang akan menimbulkan frustasi, konflik, gelisah, dan rasa bersalah yang merupakan tipe-tipe dasar stres (Anoraga, 2001). Beehr dan Newman (Rice, 1999) mengelompokkan gejala stres kerja ke dalam tiga bagian, yaitu fisik, psikis dan perilaku. Mengatasi kondisi stres kerja yang muncul diperlukan suatu strategi yang disebut coping.

Coping merupakan usaha yang dilakukan seseorang untuk menangani beban emosional atau tuntutan yang membuat stres (Lazarus, 2006). Menurut Folkman dan Lazarus (Rice, 1999) strategi coping stress dimengerti sebagai usaha kognitif serta behavioral untuk mengatasi, mengurangi ataupun upaya yang memungkinkan individu untuk bertoleransi atau tahan terhadap tuntutan-tuntutan yang muncul dalam hidupnya. Berkaitan dengan karakteristik seorang perawat sebagai profesi yang beresiko tinggi terhadap stres maka perlu ada strategi yang mampu mengatasi stres akibat tuntutan pekerjaan.

Berkaitan dengan stres kerja yang terjadi pada perawat, terdapat beberapa cara untuk meminimalisir stres yang salah satu diantaranya dengan strategi coping. Higgins dan Endler (1995) mengelompokkan strategi coping menjadi tiga kelompok utama yaitu berorientasi tugas, berorientasi emosi dan berorientasi meng- 
hindar. Ada lima jenis umum, yaitu problemfocused coping, emotional focused coping, dukungan sosial, religious coping, dan membuat makna (Safaria, Othman, \& Wahab, 2010). Penelitian ini lebih menekankan religious coping sebagai strategi untuk meminimilisir stress kerja. Koenig serta Pargament (Safaria, Othman, \& Wahab, 2010) mendefinisikan religious coping sebagai sejauh mana orang menggunakan keyakinan mereka dan praktik keagamaan untuk memfasilitasi pemecahan untuk mencegah atau mengurangi efek emosional yang negatif keadaan stres dan membantu mereka untuk beradaptasi dengan peristiwa kehidupan sulit masalah. Individu yang menggunakan religious coping sebagai strategi dalam mengatasi permasalahan yang dihadapi, memiliki kecerdasan spiritual yang baik. Individu yang menggunakan religious coping merupakan individu yang memiliki kecerdasan spiritual yang baik.

Zohar dan Marshall (2001) secara umum menjelaskan kecerdasan spiritual sebagai kecerdasan untuk memecahkan persoalan makna dan nilai, yaitu kecerdasan untuk menempatkan perilaku dan hidup dalam konteks makna yang lebih luas dan kaya serta kecerdasan untuk menilai bahwa tindakan atau jalan hidup seseorang lebih bermakna dibandingkan dengan jalan yang lain. Pencarian akan makna merupakan motivasi penting dalam hidup kita.

Individu yang cerdas secara spiritual tidak memecahkan persoalan hidup hanya secara rasional atau emosional saja. Ia menghubungkannya dengan makna kehidupan secara spiritual yaitu melakukan hubungan dengan pengatur kehidupan, sehingga dalam setiap persoalan yang dihadapinya individu mampu menyelesaikan dengan sabar dan berusaha memohon petunjuk dari Tuhan. Individu yang memiliki kecerdasan spiritual yang baik, mampu menempatkan perilaku dan menilai tindakannya, individu menghadapi pekerjaan yang padat, individu berusaha untuk mengerjakannya dengan sabar dan tanggung jawab karena dia menilai tindakannya itu lebih baik daripada individu mengerjakannya dengan mengeluh dan marah-marah sehingga kecerdasan spiritual sangat penting dalam mencegah stres kerja pada individu. Seorang yang cerdas secara ruhaniah adalah mereka yang menampilkan sosok dirinya sebagai profesional yang berakhlak. Pekerja yang membawa misi cinta, mengisi kehidupan dengan cinta, menjadikan hidupnya penuh arti (Tasmara, 2001).

Berdasarkan teori di atas menunjukkan bahwa individu yang memiliki kecerdasan spiritual yang tinggi mampu menghadapi pekerjaan yang padat dengan sabar dan bertanggung jawab sehingga diduga mampu menurunkan tingkat stres. Sebaliknya individu yang memiliki kecerdasan spiritual yang rendah, lebih sering mengeluh dan marah-marah saat mengerjakan tugas sehingga kurang mampu bersikap sabar, dan tidak mampu mengambil hikmah dibalik permasalahan yang dihadapinya sehingga rentan terhadap stres.

Stres menurut Gibson, Ivancevich, dan Donnelly (1985) sebagai suatu tanggapan adaptif muncul karena perbedaan individu atau proses psikologis yang merupakan konsekuensi dari setiap kegiatan (lingkungan), situasi atau kejadian eksternal berupa tuntutan yang berlebihan yang membebani 
kondisi psikologis atau fisik seseorang. Teori ini sejalan dengan pendapat dari Davis \& Newstrom (1992) yang mendefinisikan stres sebagai suatu kondisi ketegangan yang mempengaruhi kondisi emosi, psikis dan fisik individu.

Menurut Anoraga (1995) stres adalah suatu akibat dari tekanan emosional, rangsangan-rangsangan atau suasana yang mengganggu keadaan fisiologi individu, stres dapat mengakibatkan munculnya emosi yang bersifat negatif (tekanan), atau menimbulkan gangguan kognisi. Robbins (1998) menyebutkan stres adalah kondisi dinamik dimana seorang individu dikonfrontasikan dengan suatu peluang, kendala, atau tuntutan yang dikaitkan pada perbedaan antara harapan yang diinginkan dengan hasil yang diperoleh. Berdasarkan uraian di atas dapat disimpulkan bahwa stres adalah ketegangan dan gangguan yang tidak menyenangkan yang muncul karena adanya tuntutan-tuntutan eksternal yang menyebabkan timbulnya tanggapan fisik atau psikologis seseorang. Jamal (Yeh, Chi, \& Chiou, 2008) menjelaskan bahwa respon yang diadopsi dari seorang individu ketika ancaman muncul dari lingkungan kerja disebut stress kerja.

Menurut Anoraga (2001) gejala-gejala stres terdiri dari dua gejala yaitu gejala ringan dan gejala berat. Gejala ringan meliputi sakit kepala, vertigo, sakit maag, mudah kaget, pelupa, sukar konsentrasi, cemas, mudah marah, banyak makan, mudah bertengkar. Sedangkan gejala berat meliputi gila (psikosis), kematian dan hilangnya kontak sama sekali dengan lingkungan sosial. Cooper (Rice, 1999), mengatakan bahwa penyebab stres kerja sangat beragam dan reaksinya beragam pula pada setiap orang, yaitu a) kondisi kerja, meliputi beban kerja yang berlebihan atau beban kerja yang kurang, pengambilan keputusan, kondisi fisik yang berbahaya dan pembagian waktu kerja; b) ambiguitas dalam peran, biasanya terjadi pada organisasi yang besar dan struktur organisasi kurang baik. Karyawan kadang tidak tahu apa yang sebenarnya yang diharapkan perusahaan, sehingga ia bekerja tanpa arah yang jelas; c) faktor Interpersonal, hubungan interpersonal dalam pekerjaan merupakan faktor yang penting untuk mencapai kepuasan kerja, adannya dukungan sosial dari rekan sekerja, pihak manajemen maupun keluarga diyakini dapat menghambat timbulnya stress; d) perkembangan karier, karyawan biasanya mempunyai berbagai harapan dalam kehidupan kerier kerjanya, yang ditunjukkan dalam pencapaian prestasi dan pemenuhan kebutuhan untuk mengaktualisasikan diri; e) struktur organisasi berpotensi menimbulkan stres apabila diberlakukan secara kaku, pihak manajemen kurang memperhatikan inisiatif karyawan, tidak melibatkan karyawan dalam proses pengambilan keputusan, dan tidak adanya dukungan bagi kreatifitas karyawan.

Menurut Luthans (1995) faktor yang dapat mempengaruhi tingkat stres individu yaitu a) konflik peran, seorang karyawan memiliki peran ganda (keluarga, bekerja, profesional, rekreasi, gereja, klub, komunitas, dan sebagainya), dan ini sering membuat tuntutan yang saling bertentangan dan menciptakan harapan yang saling bertentangan; b) ambiguitas dan disposisi individu seperti pola kepribadian tipe A 
sangat berkorelasi dengan stres berkepanjangan dan konsekuensi fisik yang berbahaya; c) kontrol pribadi, perasaan orang tentang kemampuan mereka untuk mengendalikan situasi akan menjadi disposisi penting bagi stress; d) ketidakmampuan mempelajari sesuatu, orang yang paling cenderung mengalami ketidakberdayaan ketika mereka melihat penyebab dari kurangnya kontrol yang berhubungan dengan sesuatu tentang karakteristik pribadi mereka sendiri (sebagai lawan dari luar, pengaruh lingkungan); e) efikasi diri, orang dengan ekspektasi self efficacy yang tinggi memiliki alasan biologis serta psikologis untuk lebih tenang; f) ketahanan psikologis.,orang yang memiliki ketahanan psikologis mampu dan berhasil mengatasi stressor yang ekstrem.

Strategi mengatasi stres dalam penelitian ini lebih menekankan pada pendekatan personal, individu berusaha mengelola diri sendiri dalam menghadapi masalah sehingga individu akan merasa nyaman dalam bekerja dan terhindar dari stres, strategi ini sering disebut dengan strategi coping. Folkman dan Lazarus (Rice, 1999) mengemukakan bahwa strategi coping stres dimengerti sebagai usaha kognitif serta behavioral untuk mengatasi, mengurangi ataupun usaha yang memungkinkan individu untuk berorientasi atau tahan terhadap tuntutan-tuntutan yang muncul dalam hidupnya. Coping merupakan usaha yang dilakukan seseorang untuk menangani beban emosional atau tuntutan yang membuat stres (Lazarus, 2006).

Lazarus dan Folkman (Safaria, Othman, \& Wahab, 2010) mengatakan coping terbagi menjadi tiga yaitu coping yang berfokus pada permasalahan (problem focused coping), yang berfokus pada emosi (emotional focused coping) dan maladaptif coping. Berkaitan dengan stres kerja yang terjadi pada perawat, salah satu cara untuk meminimalisir stres yaitu dengan strategi coping, dalam penelitian ini penulis menghubungkan dengan salah satu coping yaitu emotional focused coping. Menurut Sarafino (1994) Emotional focused coping adalah merupakan pengaturan respon emosional dari situasi yang penuh stres. Individu dapat mengatur respon emosinya dengan beberapa cara, antara lain yang biasa digunakan individu dalam pengaturan emosinya adalah dengan berfikir dan memberikan penilaian mengenai situasi yang stressfull.

Penelitian ini menggunakan kecerdasan spiritual sebagai pendekatannya dengan strategi mengatasi stres pada individu yang diukur dengan tingkat kecenderungan perilaku spiritual yang dimiliki seseorang. Kecerdasan spiritual atau Spiritual intelligence dapat dikatakan sebagai sebuah konsep baru dalam dunia psikologi. Konsep kecerdasan spiritual ini pertama kali dikemukakan pada akhir abad ke dua puluh oleh Zohar dan Marshall, akan tetapi kecerdasan spiritual barat atau Spiritual intelligence tersebut belum atau bahkan tidak menjangkau ketuhanan.

Zohar dan Marshall (2001) secara umum menjelaskan kecerdasan spiritual sebagai kecerdasan untuk memecahkan persoalan makna dan nilai, yaitu kecerdasan untuk menempatkan perilaku dan hidup dalam konteks makna yang lebih luas dan kaya serta kecerdasan untuk menilai bahwa tindakan atau jalan hidup seseorang lebih 
bermakna dibandingkan dengan jalan yang lain. Pencarian akan makna merupakan motivasi penting dalam hidup kita. Khavari (Zohar \& Marshall, 2001) menyatakan bahwa kecerdasan spiritual adalah fakultas dari dimensi non material kita-ruh manusia. Inilah intan yang belum terasah yang semua manusia memilikinya. Individu harus mengenalinya seperti apa adanya, menggosok sehingga berkilap dengan tekad yang besar dan kecerdasan lainnya (kecerdasan intelegensi dan kecerdasan emosi), kecerdasan spiritual dapat ditingkatkan dan diturunkan. Kemampuannya untuk ditingkatkan tampaknya tidak terbatas.

Agustian (2002) mendefinisikan kecerdasan spiritual sebagai kemampuan untuk memberi makna ibadah terhadap setiap perilaku dan kegiatan, melalui langkah-langkah dan pemikiran yang bersifat fitrah, menuju manusia yang seutuhnya (hanif) dan memiliki pola pemikiran tauhid (integralistik), serta berprinsip "karena hanya Allah SWT". Menurut Tasmara (2001), kecerdasan ruhaniah atau kecerdasan spiritual sebagai kemampuan seseorang untuk menjalani hidupnya dengan tetap berpadukan kepada cahaya Illahi yang menerangi qolbu sebagai pusat dirinya mengambil keputusan. Qolbu atau hati nurani akan menjadi pembimbing seseorang untuk menentukan apa yang harus ditempuh dan apa yang harus diperbuat dalam menghadapi perubahan kehidupan yang cepat dan dinamis. Menurut Vaughan (2003), kecerdasan spiritual mengisyaratkan kapasitas pemahaman yang mendalam mengenai eksistensial pertanyaan dan wawasan tentang berbagai tingkat kesadaran. Kecerdasan spiritual juga menyiratkan kesadaran semangat sebagai dasar menjadi atau sebagai kekuatan hidup kreatif evolusi.

Berdasarkan pemaparan beberapa ahli tentang pengertian kecerdasan spiritual, maka dapat disimpulkan bahwa definisi kecerdasan spiritual dalam penelitian ini adalah kemampuan seseorang untuk menjalani hidupnya dengan memberi makna ibadah terhadap setiap perilaku dan kegiatannya melalui langkah-langkah dan pemikiran yang bersifat fitrah, menuju manusia yang seutuhnya (hanif) dan memiliki pola pemikiran tauhid (integralistik), serta berprinsip "karena hanya Allah SWT".

Zohar dan Marshall (2001) menyebutkan bahwa komponen yang ada dalam kecerdasan spiritual meliputi a) kemampuan bersikap fleksibel (adaptif secara sepontan dan aktif); b) tingkat kesadaran yang tinggi; c) Kemampuan menghadapi dan memanfaatkan penderitaan; d) kemampuan untuk menghadapi dan melampaui rasa sakit; e) kualitas kehidupan yang diilhami oleh visi dan niali-nilai; f) keengganan untuk menyebabkan kerugian yang tidak perlu; g) kecenderungan untuk bertanya-tanya "mengapa" atau "bagaimana" untuk mencari jawaban-jawaban yang mendasar; h) bertanggung jawab untuk membawakan misi dan nilai pada orang lain (memberikan inspirasi pada orang lain)

Coping merupakan usaha yang dilakukan seseorang untuk menangani beban emosional atau tuntutan yang membuat stres (Lazarus, 2006). Menurut Folkman dan Lazarus (Rice, 1999) strategi coping stress dimengerti sebagai usaha kognitif serta behavioral untuk mengatasi, mengurangi 
ataupun upaya yang memungkinkan individu untuk bertoleransi atau tahan terhadap tuntutan-tuntutan yang muncul dalam hidupnya. Berkaitan dengan karakteristik seorang perawat sebagai profesi yang beresiko tinggi terhadap stres maka perlu ada strategi yang mampu mengatasi stres akibat tuntutan pekerjaan. Strategi tersebut dapat menggunakan strategi coping. Lazarus dan Folkman (Safaria, Othman, \& Wahab, 2010) mengatakan coping terbagi menjadi tiga yaitu coping yang berfokus pada permasalahan (problem focused coping), yang berfokus pada emosi (emotional focused coping) dan maladaptif coping.

Berkaitan dengan stres kerja yang terjadi pada perawat, terdapat beberapa cara untuk meminimalisir stres yang salah satu diantaranya dengan strategi coping. Penelitian ini penulis menghubungkan salah satu coping yaitu emotional focused coping. Menurut Sarafino (1994) Emotional focused coping adalah merupakan pengaturan respon emosional dari situasi yang penuh stres. Emotional focused coping terdiri dari mencari dukungan sosial dengan alasan emosional, reinterpretasi dan pertumbuhan yang positif, penolakan, penerimaan, kembali dalam agama. Salah satu yang termasuk kembali dalam agama yaitu kecerdasan spiritual.

Kecerdasan spiritual merupakan faktor penting yang dapat membantu dan mengarahkan seseorang agar mampu menghadapi situasi lingkungan kerja yang menekan. Kecerdasan spiritual menurut Tasmara, (2001) adalah kecerdasan manusia yang digunakan untuk "berhubungan" dengan Tuhan. Sebuah kecerdasan yang berpusat pada rasa cinta yang mendalam kepada Tuhan, dengan menjadikan Tuhan sebagai landasannya ketika dihadapkan persoalan hidup. Berdasarkan teori dan hasil penelitian yang telah diuraikan di atas, diajukan hipotesis bahwa ada hubungan negatif antara kecerdasan spiritual dan stress kerja yaitu semakin tinggi kecerdasan spiritual maka semakin rendah stres kerja. Sebaliknya semakin rendah kecerdasan spiritual maka semakin tinggi stres kerja.

\section{METODE PENELITIAN}

\section{Subjek Penelitian}

Subjek dalam penelitian ini adalah perawat Rumah Sakit Islam Klaten dari bagian Unit Gawat Darurat dan bagian Rawat Inap. Kriteria subjek adalah perawat Rumah Sakit Islam Klaten yang sudah menjadi karyawan tetap. Hal ini dikarenakan perawat yang telah menjadi karyawan tetap dimungkinkan memahami dan melaksanakan tuntutan-tuntutan pekerjaan yang telah ditetapkan di Rumah Sakit.

\section{Alat Ukur}

Metode pengumpulan data yang digunakan dalam penelitian ini adalah angket yang berbentuk skala. Alat ukur yang digunakan dalam penelitian ini ada dua skala yaitu skala stres kerja dan skala kecerdasan spiritual.

Skala stres kerja digunakan untuk mengukur stres kerja pada perawat, skala ini terdiri dari dua bagian yaitu petunjuk pengisian skala dan lembar aitem. Aitemaitem soal disusun berdasarkan gejala stres kerja dari teori dibuat berdasarkan Beehr dan Newman (Rice, 1999) yaitu gejala fisiologis, gejala psikologis, dan gejala 
perilaku. Skala ini terdiri dari 24 aitem, 17 aitem favorable dan 7 aitem unfavorabe. Skala stres kerja menjadi 24 aitem dengan koefisien korelasi total bergerak antara 0,322 sampai dengan 0,703 . Hasil analisis reliabilitas pada skala stres kerja memiliki koefisien reliabilitas 0,923 artinya skala stres kerja dapat digunakan sebagai alat pengumpul data dalam penelitian karena memiliki keandalan yang cukup baik (reliabel).

Skala kecerdasan spiritual yang digunakan pada perawat dalam pembuatan skala ini penulis mengacu pada aspek dari teori Tasmara (2001) yaitu takwa, memiliki makna hidup, akhlak mulia, memandang segala sesuatu dengan cinta, dan memiliki kebahagiaan. Skala ini terdiri dari 40 aitem, 21 aitem favorable dan 19 aitem unfavorable. Skala kecerdasan spiritual menjadi 40 aitem dengan koefisien korelasi total bergerak antara 0,320 sampai dengan 0,683 . Hasil analisis reliabilitas pada skala stres kerja memiliki koefisien reliabilitas
0,924 artinya skala stres kerja dapat digunakan sebagai alat pengumpul data dalam penelitian karena memiliki keandalan yang cukup baik (reliabel).

\section{HASIL PENELITIAN}

\section{Deskripsi Subjeks}

Penelitian dilaksanakan di Rumah Sakit Islam Klaten khususnya pada perawat khususnya perawat bagian UGD dan rawat inap. Jumlah digunakan sebagai subjek penelitian adalah 101 subjek.

\section{Hasil Uji Asumsi}

1. Uji Normalitas

Pengujian normalitas menggunakan teknik statistik one-sample kolmogrovsmimov test dari program SPSS 15.0 for windows. Kaidah yang digunakan adalah jika p > 0,05 maka sebarannya dinyatakan normal dan sebaliknya jika $\mathrm{p}<0,05$ maka sebarannya dinyatakan tidak normal.

Tabel 1. Uji Normalitas Sebaran

\begin{tabular}{cccc}
\hline Variabel & Skor KS-Z & Sig & Keterangan \\
\hline Stres Kerja & 0,714 & 0,688 & Normal \\
Kecerdasan Spiritual & 0,829 & 0,498 & Normal \\
\hline
\end{tabular}

Berdasarkan hasil analisis uji normalitas yang tertera pada tabel 1, diketahui bahwa variabel stres kerja memiliki skor KS-Z sebesar 0,714 dengan p $=0,688(\mathrm{p}>0,05)$ sehingga variabel stres kerja memiliki sebaran normal, variabel kecerdasan spiritual memiliki skor KS-Z sebesar 0,829 dengan $p=0,498(p>0,05)$ sehingga variabel kecerdasan spiritual memiliki sebaran normal.

\section{Uji Linieritas}

Uji linieritas merupakan pengujian garis regresi antara variabel bebas dan variabel tergantung. Pengujian ini bertujuan untuk melihat apakah dari sebaran titik-titik yang merupakan nilai dari variabel-variabel penelitian dapat ditarik garis lurus yang menunjukkan sebuah hubungan linier antara variabel-variabel tersebut. Kaidah 
yang digunakan untuk mengetahui linier tidaknya hubungan antara variabel bebas dengan variabel tergantung adalah $\mathrm{p}<0,05$ maka hubungan dinyatakan linier dan jika $p$ $>0,05$ maka hubungan dinyatakan tidak linier.

Hasil pengujian hubungan antara variabel stres kerja dan kecerdasan spiritual menunjukkan nilai $F$ linieritas (F) sebesar 11,546 dengan taraf signifikan (p) sebesar $0,001(p<0,05)$ yang berarti ada hubungan linier atau membentuk garis lurus antara kedua variabel tersebut karena lebih kecil dari 0,05 maka dapat dikatakan hubungan antara kedua variabel yaitu stres kerja dan kecerdasan spiritual adalah linier.

\section{Hasil Uji Hopotesis}

Hipotesis yang menyatakan bahwa ada hubungan yang negatif antara kecerdasan spiritual dengan stres kerja yang diuji dengan menggunakan koefisien korelasi product moment dengan bantuan program SPSS 15.0 for windows. Berdasarkan hasil analisis diketahui bahwa besarnya koefisien korelasi antara kedua variabel tersebut $\left(\mathrm{r}_{\mathrm{xy}}\right)=-0,315$ dan probabilitas $\mathrm{p}=0,001(\mathrm{p}<0,01)$, maka terdapat korelasi negatif yang sangat signifikan antara variabel kecerdasan spiritual dengan stres kerja, sehingga hipotesis yang diajukan dalam penelitian ini benar. Peneliti yang melakukan analisis untuk mengetahui seberapa besar sumbangan variabel bebas terhadap variabel tergantung. Hasil analisis menunjukkan bahwa nilai koefisien determinan $r^{2}=0,099$, hal ini menunjukkan bahwa variabel kecerdasan spiritual memberi pengaruh $9,9 \%$ terhadap variabel stres kerja.

\section{PEMBAHASAN}

Hasil analisis menunjukkan ada hubungan negatif yang sangat signifikan antara kecerdasan spiritual dengan stres kerja pada perawat di Rumah Sakit Islam Klaten. Semakin tinggi kecerdasan spiritual maka akan semakin rendah stres kerja pada perawat, sebaliknya semakin rendah kecerdasan spiritual maka akan semakin tinggi stres kerja pada perawat. Hal ini diketahui dari koefisien korelasi yang diperoleh dalam penelitian ini antara kedua variabel tersebut $\left(r_{x y}\right)=-0,315$ dan probabilitas $p=0,001(p<$ 0,01), maka terdapat korelasi negatif yang sangat signifikan antara variabel kecerdasan spiritual dengan stres kerja. Selain itu, berdasarkan kategori kedua variabel penelitian yaitu stres kerja dalam kategori sedang sebesar $78,22 \%$ yang menunjukkan dari 101 perawat, 79 perawat yang memiliki stres kerja sedang dan kecerdasan spiritual dalam kategori tinggi sebesar 95,05\% yang menunjukkan dari 101 perawat, 96 perawat yang memiliki kecerdasan spiritual tinggi.

Penelitian ini sejalan dengan penelitian yang dilakukan oleh Azad-Marzabadi, Hoshmandja, dan Poorkhalil (2013) yang menyatakan bahwa ada hubungan negatif yang signifikan antara kecerdasan spiritual dan stres kerja. Hal tersebut dikarenakan bahwa spiritualitas dan kecerdasan spiritual dapat membantu meningkatkan kesehatan mental dan gangguan mental yang lebih rendah dalam jangka panjang. Kesejahteraan spiritual dapat meningkatkan kesehatan mental dan membantu individu mengatasi masalah hidup mereka dengan meningkatkan kesadaran diri mereka, membuat ikatan antara mereka dan orang lain, menerima 
dukungan sosial dari orang lain, meningkatkan kepercayaan diri mereka dan makna hidup, dan mengajari mereka strategi yang efektif dalam berurusan dengan masalah emosional

Penelitian yang dilakukan oleh Mashhad, Mobarakeh, dan Jam (2013) juga menunjukkan bahwa ada hubungan negatif yang signifikan antara kecerdasan spiritual dan komponen stres kerja yaitu lingkungan fisik; ambiguitas peran dan konflik pekerjaan, hal tersebut disebabkan karena orangorang yang memiliki kemampuan untuk menghadapi masalah akan mengurangi stress

Peneliti juga melakukan analisis untuk mengetahui berapa sumbangan efektif variabel bebas dalam mempengaruhi variabel tergantung. Hasil analisis menunjukkan bahwa koefisien determinan $\left(\mathrm{r}^{2}=0,099\right)$, hal ini menunjukkan bahwa variabel kecerdasan spiritual memberi sumbangan efektif sebesar 9,9\% dalam mempengaruhi stres kerja pada perawat, sedangkan sisanya 90,1\% dipengaruhi oleh variabel lain. Adapun variabel lain yang berpengaruh terhadap penurunan stres kerja antara lain coping stress yang terdiri dari problem focused coping seperti perencanaan dengan merencanakan tindakan coping yang akan dilakukan dan merencanakan langkahlangkah yang akan diambil, berkonsentrasi menghadapi stressor dan menghindari aktivitas lain yang dapat mengganggu, menahan diri dengan menunggu hingga mendapatkan kesempatan yang tepat untuk bertindak dan tidak gegabah dalam bertindak. Emotional focused coping selain kecerdasan spiritual seperti dukungan sosial dengan berusaha mendapatkan dukungan moral, simpati atau pengertian dari orang lain, reinterpretasi dan pertumbuhan yang positif dengan memberikan penilaian yang positif dari situasi problematik yang terjadi, penolakan dengan bertindak seolah-olah stressor tersebut tidak ada, dan penerimaan dengan cara individu bersikap pasrah dengan keadaan yang dihadapi dan menerima kejadian tersebut karena tidak ada yang bisa dirubah. Strategi coping memainkan peranan penting dalam mempertahankan kesehatan dan kesejahteraan individu selama berada dalam situasi menekan (Skinner \& Zimmer-Gembeck, 2009).

Upaya untuk menurunkan tingkat stres individu tak hanya dengan menggunakan stategi coping tetapi dapat dengan teknik untuk menurunkan stres. Menurut Atkinson, Atkinson, Smith, \& Bem, (2002) terdapat beberapa teknik yang dapat membantu seseorang menurunkan efek stres yaitu dengan menggunakan teknik perilaku seperti biofeedback (individu menerima informasi umpan balik tentang suatu aspek keadaan fisiologis mereka dan kemudian berupaya mengubah keadaan itu), latihan relaksasi (belajar bagaimana caranya relaks), dan latihan aerobic (aktivitas yang dilakukan secara cepat untuk meningkatkan kecepatan denyut jantung dan konsumsi oksigen seperti jogging, berenang dan bersepeda). Teknik kognitif dengan difokuskan pada perubahan respon kognitif individual terhadap situasi stres, terapi ini berupaya membantu orang mengidentifikasi situasi stres yang menghasilkan gejala fisiologis atau emosional dan mengubah cara individu menghadapi situasi tersebut.

Pada penelitian ini kecerdasan spiritual di Rumah Sakit di Klaten tergolong 
tinggi yaitu 95,05\% dari 101 perawat. Mengingat rumah sakit tempat penelitian merupakan rumah sakit yang bernuansa islami sehingga manajemen memperhatikan aspek spiritual dalam menjalankan proses kerja dalam organisasi, yaitu dengan memberikan kegiatan keagamaan dengan diadakannya pengajian setiap satu bulan sekali. Selain itu juga adanya fasilitas untuk beribadah yang memadai dan juga kebijakan dari pihak Rumah Sakit di Klaten yang memberikan waktu kepada perawat untuk dapat menjalankan ibadah shalat berjamaah. Kondisi menunjukkan bahwa sejalan dengan hasil penelitian Azad-Marzabadi, Hoshmandja, \& Poorkhalil (2013) yang meneliti tentang hubungan antara spritualitas organisasi dan stress kerja, hasilnya menunjukkan bahwa ada korelasi negatif antara spiritualitas organisasi dan stres kerja. Hal tersebut disebabkan kesejahteraan agama dapat memprediksi kesehatan mental.

Sebagai contoh, pasien dengan nyeri kronis yang sulit untuk percaya pada Tuhan dan merasa bahwa Tuhan telah meninggalkan mereka karena kurang pengalaman spiritual, tidak menerima dukungan dari komunitas agama, dan tidak menganggap diri mereka kurang religius. Pasien-pasien ini kemungkinan lebih mudah mengalami gangguan kesehatan mental. Tampaknya kemarahan terhadap Tuhan karena memiliki perasaan ditinggalkan berkorelasi dengan lemahnya kesehatan mental dan rendahnya tingkat strategi pemecahan. Oleh karena itu, spiritualisme dan agama dapat bekerja seperti perisai terhadap masalah dan tekanan yang dihadapi dan dapat membantu mengurangi gangguan mental dan meningkatkan kesehatan mental.

\section{SIMPULAN DAN SARAN}

\section{Simpulan}

Kesimpulan dari hasil penelitian yang telah dilakukan adalah bahwa ada hubungan negatif yang sangat signifikan antara kecerdasan spiritual dengan stres kerja pada Perawat di Rumah Sakit di Klaten. Semakin tinggi kecerdasan spiritual maka akan semakin rendah stres kerja dan sebaliknya semakin rendah kecerdasan spiritual maka akan semakin tinggi stres kerja pada Perawat di Rumah Sakit di Klaten.

\section{Simpulan}

Berdasarkan hasil penelitian, pembahasan dan kesimpulan yang menyebutkan adanya hubungan negatif yang sangat signifikan antara kecerdasan spiritual dengan stres kerja, maka peneliti merekomendasikan beberapa saran. Pertama, peneliti menyadari bahwa penelitian ini masih banyak kekurangan dikarenakan dalam penelitian ini hanya mengkaji variable kecerdasan spiritual padahal masih banyak faktor-faktor lain yang dapat mengurangi stres kerja, sehingga pada penelitian selanjutnya. Selain itu kecerdasan spiritual hanya memberikan sumbangan yang kecil untuk menurunkan tingkat stres. Peneliti lain disarankan agar dapat meneliti dan mengembangkan variabel-variabel lain yang dapat memperkaya hasil penelitian mengenai cara menurunkan stres kerja, seperti dukungan sosial, teknik perilaku seperti biofeedback dan latihan aerobic. Selain itu 
diharapkan pula untuk peneliti selanjutnya dapat menggunakan teori spiritual berdasarkan literatur-literatur yang ilmiah seperti jurnal sebagai acuan dasar dalam menentukan aspek-aspek dalam pembuatan alat ukur.

Kedua, hasil penelitian ini diharapkan bagi perawat agar dapat mereduksi tingkat stres dengan mengembangkan emotional focused coping yang lain. Seperti mencari dukungan sosial dengan cara menceritakan permasalahannya pada orang terdekat diantaranya rekan kerja saat menghadapi tekanan dalam pekerjaan sehingga dapat mengurangi beban yang dirasakan sehingga dapat menurunkan tingkat stres. Memberikan penilaian positif terhadap situasi problematik yang dihadapi, menerima dengan bersikap pasrah terhadap masalah yang dihadapi.

Ketiga, hasil penelitian ini dapat dijadikan kontribusi dalam menghindari stres kerja yang terjadi pada perawat dengan berupaya menciptakan kondisi kerja yang baik seperti dengan pengambilan keputusan yang partisipatif, perubahanperubahan struktural dengan memberikan kontrol yang lebih atas pekerjaan perawat. Memberikan fasilitas olahraga bagi perawat, pengajian, dan pembinaan dengan memotivasi perawat dalam melaksanakan tugasnya agar lebih memahami bahwa profesinya rentan terhadap stres, serta berkomunikasi dengan efektif antar sesama perawat maupun atasan.

\section{DAFTAR PUSTAKA}

Agustian, A. G. (2002). ESQ: Rahasia sukses membangun kecerdasan emosi dan spiritual. Jakarta: Arga.

Anoraga, P. (2001). Psikologi kerja. Jakarta: Rineka Cipta.

Anoraga, P., \& Suyati, S. (1995). Psikologi industri dan sosial. Jakarta: PT. Pustaka Jaya.

Atkinson, R. L., Atkinson R. C., Smith, E. E., \& Bem, D. J. (2002). Pengantar psikologi (11 th ed). (Widjaja Kusuma). Batam: Interaksara.

Azad-Marzabadi, E., Hoshmandja, \& Poorkhalil. (2013). The relationship between personnel's job stres and their spiritual intelligence and organizational spirituality in a Military University. Iranian Journal of Military Medicine, 15 (1), 45- 52

Davis, K., \& Newstrom, J.W. (1992). Perilaku dalam organisasi. ( $7^{\text {th }}$ ed). (Dharma, A). Jakarta: Erlangga.

Gibson, J.L., Ivancevich, J.M., \& Donnelly, J.H. (1985). Organisasi perilaku struktur proses ( 5 th ed). (Adiarni, N). Jakarta: Erlangga.

Lazarus, R.S., \& Lazarus B.N. (2006). Coping with aging. New York: Oxford.

Mashhad., Mobarakeh., \& Jam. T. (2013). Job stress and spiritual intelligence: A 
case study. World Applied Sciences Journal, 22 (11), 1667-1676.

Rice, P.L. (1999). Stress and Health (3rd ed). Pasific Grove California: Brooks/Cola Publishing Company.

Robbins, S.P. (1998). Perilaku organisasi. (Angelica, D). Jakarta: Salemba Empat.

Safaria, T., Othman, B. A., \& Wahab, M. N. A. (2010). Religious coping, job insecurity and job stress among javanese academic staff: A moderated regression analysis. International Journal of Psychological Studies, 2, 2, 159-169.

Sarafino, E. P. (1998). Health psychology biopsychosocial interactions ( $3^{\text {rd }}$ ed). New York: John Wiley \& Sons.

Skinner, E. A., \& Zimmer-Gembeck, M. J. (2009). Challenges to the developmental study of coping. New Directions for Child and Adolescent Development. San Francisco: Jossey-Bass.
Tasmara, T. (2001). Kecerdasan ruhaniah (transcendental intelligence): membentuk kepribadian yang bertanggung jawab, professional, dan berakhlak. Jakarta: Gema Insani.

Vaughan, F. (2003). What is spiritual intelligence?. Journal of Humanistic Psychology, 42 (2) 16-33.

Yeh, H.R., Chi, H.K., \& Chiou, C.Y. (2008). The influences of paternalistic leadership, job stress, and organizational commitment on organizational performance: An empirical study of policemen in Taiwan. The Journal of International Management Studies, 3, 2, 85-92.

Zohar, D., \& Marshall, I. (2001). SQ: Memanfaatkan kecerdasan spiritual dalam berfikir integralistik dan holistic untuk memaknai hidup. (Rahmani Astuti, Ahmad Najib Burhani, \& Ahmad Baiquni). Bandung: Mizan. 